\title{
ON THE CHEMOTHERAPY OF MURINE LEPROSY
}

\section{Norimasa HIRANO and Kiyo SUSHIDA}

(Dept. of Bacteriology, Tokyo Women's Medical College)

As the results of the treatment and inhibition of isonicotinoyl-3-methoxy-4-hydroybenzal hydrazone upon murine leprosy, following facts were obtained.

1. The subcutaneous injection or per os administration of it in the mice which had developed marked murine leprous ulcer or nodules completely cured the lesions, after a few months, and the continuation can make disappear the acid-fast bacilli from the visceral organs. Then even in the inoculated site, the discovery was very difficult and only several of them could be found even in one field.

2. After the healing of the murine leprous ulcer, the discontinuation of treatment provoked sometimes the recidive and retreatment seemed to have no effect against the recidive-ulcer. Perhaps, incomplete treatment might get the acid-fast bacilli some resistance. But after studies can clarify the problems of this point.

3. After the treatment of several weeks of healing of the inoculated site, the muscles of the inoculoted site were again transplanted upon the normal mice. By six months afterwards, any involvement of murine leprosy were not seen except only one case after seven months, and others remained without any changes. When the treatment of this drug can be continued for the longer period, the murine bacillus may be unable to survive.

4. The daily administration of ison:cotinoyl-3-methoxy-4-hydroxybenzal hydrazane in $10 \mathrm{mg}$ after a week of inoculation of the murine leprosy bacilli upon the mice, not only the onset of the disease was inhibited, but also the acid-fast bacilli in the inoculated site were not found. In the groups of animals administered $1 \mathrm{mg}$ the onset was strikingly prevented, namely, in 3 of 12 mice, the acid-fast bacilli were quite negative, in 7 only in a few number and a number of them were recognized only in one mouse, while remarkable onset and innumerable bacilli were found in the control animals.

6. The above results lead us to a conclusion that isonicotinoyl-3-methoxy-4-hydroxybenzalhydrazone acts as a bacteriocidal drug upon the murine leprosy bacillus.

\section{鼠癩の化学療法について}

\section{東京女子医科大学細菌学教室 \\ 平野憲正須子田キヨ}

（昭和 31 年 7 月 27 日受稿）

\footnotetext{
Isonicotinic acid hydrazide (INAH) が鼠瘦の発症を

著しく阻止することは, 多くの学者 (Chang(1), Hobby and Donikian ${ }^{(2)}$, 西村 ${ }^{3}$, 川口 ${ }^{4}$, 高山市, 市原 ${ }^{6}$ 等) によ つて報告されている。われわれは本剤の誘導体につい
}

て, 結核及び鼠瀨に対する作用を研究中, Isonicotinoyl -3-methoxy-4-hydroxybenzal hydrazone (以下 No. 254 と記るす）を著明な潰瘍を有するラッテの静脈内に注射 したところ，わずかに 2 週間にして治瘾したととを認め 
たので，これが偶然か，否かを確めるために，本実験を 行つた。No. 254 の化学構造は次のようである。<smiles>COc1ccc(O)cc1</smiles>

本剤は三共高峰研究所砂川立俊氏によつて合成され， 結核の化学療法研究のため,254 番目に実験されたので, 仮りに No. 254 とした。

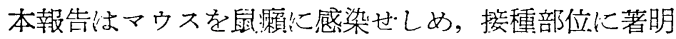
な結節もしくは潰济が発生したものについて，治療試驗 を行つた成績と，本剤を経口的に与えた場合に於ける発 症阻止試験の成績である。

\section{実 験 方 法}

No. 254 は黄色の粉末でむつて，水に溶解しないけれ ぞも，少量のアルカリを加えて加熱すると溶解する。わ れわ机 $0.05 \mathrm{~g}$ に蒸溜水もしくは生理食塩水 $4.3 \mathrm{cc}$ と $10 \% \mathrm{Na}_{2} \mathrm{CO}_{3} 0.7 \mathrm{cc}$ を加え，重湯煎で加熱溶解した。

本剂保経口的には，相当の大量を与えることができ る。しかし，静脈内注射を行 $0.35 \mathrm{~g}$ per $\mathrm{kg}$ (マウス体重)以上である。注射する場合 は，極めて徐々に行わなけれ代，注射中にマウスは敝れ る。

\section{治療試験}

マウスの臘部皮下にハワイ株を接種し，約 3 ～4 カ 後著明な結節もしくは潰瘍が現われてから治療試験を行 つた。治療を終つたマウスについては, 接種部位の筋肉 を切りとつて塗抹標本を作り，抗酸性菌の有無を椧索し た。二・三のマウスに於ては，その筋肉を磨矿して，健 䐂マウスの皮下に接種し，その部に於ける抗酸性菌が， 感染力をもつているか，否かを検查した。またそれ等の マウスの脾臓及び肝臓を病理組織学的に椧討した。治療 試験は 3 回行つたが，治療に就ての大体の見当をつける ために，総計 15 匹について行つた。

実験 [ : 約 4 力月前にハワイ株を接種した 4 匹のマウ スに，No. 254 を毎日（日曜を除く）皮下に $0.7 \mathrm{mg}$ 注 射した。 $5 ち 2$ 匹に於ては, 潰瘍の治癒後治療を中止 し，潰瘍が再発するか，どらかを観祭した。

実験 2 : 前実験の繰り返えしであつて, 約 3 カ月前に ハワイ株を䏚部皮下に接種し，著明な病変の現れた 8 匹 のマウスの皮下に，No. 254を $0.7 \mathrm{mg}$ 毎日（日曜を除 く）皮下に注射した。この実験に於ては，接種部に於け る抗酸性菌の消失する時期を明らかにしようと思つて, 治療期間を種々にした。
実験 3 ：本郕を経口的に与えた場合の効果を知ろうと して行つた実験で出つて，約 4 力月前㑷本株をマウス の脸部皮下接種し，著明な結節もしくは潰瘍が認められ た 3 迄に，No. 254 を $0.015 \mathrm{~g}$ 蜂蜜に混ぜて，毎日経口 的に与えた。 $0.015 \mathrm{~g}$ という量は，1 回の投与量として は，非常な大量で岁るが，かよらな大量の連日投与に， マウスが果して耐えるか，否かを知るために，かような 量を与えたのである。

\section{発症阻止試験}

この笑験には雌のマウス（dd）が用いられた。1 群の マウスは 13 爬とし，各群に頙結節（ハワイ株）から作 つた菌の浮游液を，0.2 cc 胸部皮下に接種し，接種後 7 日目から， 1 群には No. 254 学 $10 \mathrm{mg} ， 2$ 群には $1 \mathrm{mg}$ を每日（日矅を除く）蜂蜜に混ぜて経口的红与え，3 群 は治療せずに対照とした。鼠瀨菌姜種後 3 力月目に，各 群のマウスを剖検し，接種部の組織，肝臓及び脾臓から 等抹標本を作つて，抗酸性菌を検查した。

\section{結 果}

治潦試験（実験 $1 〜 3$ ）の成績は表 1 に総括した。

Table 1. The chemotherapeutic effect of isonicotinoyl -3-methoxy-4-hydroxybenzal hydrazone against the subcutaneous infection with M. leprae murium in white mice

\begin{tabular}{|c|l|c|c|c|}
\hline $\begin{array}{l}\text { Animal } \\
\text { No. }\end{array}$ & Local lesion & $\begin{array}{l}\text { Duration of } \\
\text { treatment }\end{array}$ & Route & $\begin{array}{c}\text { Number of organisms } \\
\text { observed in tissue }\end{array}$ \\
\hline a & Ulcer & 47 & S. C. & few \\
b & Ulcer & $83 \neq$ & S. C. & + \\
c & Ulcer & 83 . & S. C. & + \\
d & Ulcer & 79 & S. C. & very few \\
\hline 1 & Leprom & 112 & S. C. & very few \\
\hline 2 & Ulcer & 78 & S. C. & - \\
3 & Leprom & 84 & S. C. & very few $\ddagger$ \\
4 & Ulcer & 127 & S. C. & - \\
\hline 5 & Ulcer & 61 & S. C. & very few \\
6 & Ulcer & 60 & S. C. & - \\
\hline 7 & Ulcer & 90 & S. C. & few \\
8 & Ulcer & 125 & S. C. & - \\
\hline 9 & Ulcer & 108 & per os & few $\ddagger$ \\
\hline 10 & Leprom & 61 & per os & few $\ddagger$ \\
\hline
\end{tabular}

S. C. Drug given subcutaneously

\# replased.

+ diex

I The tissue emulsion was inoculated subcutaneouly into normal mice.

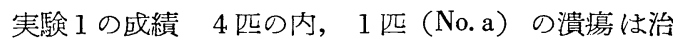
療後 47 日目に完全に治瘾した。このマウスを殺して, 接種部の筋肉を切りとり，塗抹標本を作つて染色検査し たととろ，少数ながら抗酸性菌が認められた。他の 3 四 
(No. b, c, d) の㣴癔は, 治療開始後 3 力月以内に治癒 し, 治瘾後 7 日目から治療を中止して, 経過 是観察し た。その結果， 1 匹 (No.b) は 3 日後に, 他の 1 比(No. c) は 1 カ月後にいずれも再発し，脸部に小浿㾤が発生 し，その部に抗酸性菌が証明された。残りの 1 迎 (No. d) は約 1 力月に整死し，接種部から極めて少数の抗酸 性菌が険出された。

実験 2 の成績 実験に用いた 8 匹のマウスの謴瘴は， 治療を始めてから，25一78 日平均 60 日で全部治癋し， その後な怙 2 力月治療を続けた。その間に死んだ 3 匹 (No. 1, 2, 3) と，他に2 匹 (No. 5,6) を殺して，各 接種部位の筋肉及びその附近の淋巴腺を榆査したが，抗 酸性菌は 1 視野 1 一数コ証明されたのみであつた。その 内 1 匹 (No.3) の撄種部組織をとつて磨础し， 3 匹の 健䐂マウスの皮下に接種した。その後 7 カ月を経過した けれども，未だ発症を認めない。残り 3 匹 (No. 4, 7, 8）のマゥスは，治療閒始後 130 日目に殺し，鼠癩菌接 種部位の筋肉及びその附近の淋巴腺から塗抹標本を作つ て榆查したが，抗酸性菌は証明されなかつたか，骤めて 僅に認められたに過ぎなかつた。この内 2 匹 (No.4,8) のマウスの接種部組織を磨砕して，健康マウスの胸部皮 下に接種した。その結果，No. 4 のマウスの組織を接種 したマウスに於てのみ, 接種後 7 カ月後に発症が証明さ れ，No. 8 の組織を接種したマウスに於ては，未だ異常 を認めたい。

とれ等マウスの脾臓, 肝臟及び腎䑏を病理組織学的に 㭘查したが，瀨結節は殆んど認められず，抗酸性菌も証 明されなかつた。

実験 3 の成績 実験に用いた 3 匹の内， 1 匹は途中で 死んだが，他の 2 匹の潰瘍は，1 カ月以内に治癒した。 その後な怙治療を続け，1 匹（No. 10）は治療開始後 61 日目に殺し，鼠瀬菌を接種した部位の筋肉を検したとと ろ， 1 視野に約 20 二程度の抗酸性菌を認めた。その部 分の筋肉を磨砕して，健康マウス 3 匹の胸部皮下に接種 し，既に6 カ月を経過したけれども，末だ発症を認めな い。他の 1 匹 (No.9) は治療開始後 108 日に死んだ。 このマウスの胸部筋肉には，僅に抗酸性菌を認めた。そ の部の筋肉を健唐マウスに接種したが， 5 カ月後の今日 未だ結節は証明されない。

2 匹 (No.9 及び 10) とも病理組織学的には, 脾㵴 及び肝㵴に癩結節が認められたけれども，その数少く， 大きさも非常に小さく，その部に抗酸性菌は証明されな 加つた。

発症阻止試験成績
Table 2. The chemotherapeutic effect of isonicotnoyl -3-methoxy-4-hydroxybenzal hydrazone against the infection with $\mathrm{M}$. leprae murium in white mice. Daily treatment for 53 days after the infection.

\begin{tabular}{|c|c|c|c|c|}
\hline \multirow{2}{*}{$\begin{array}{l}\text { Animal } \\
\text { No. }\end{array}$} & \multirow{2}{*}{$\begin{array}{c}\text { Daily dose } \\
\qquad\left(\mathrm{mg}_{\mathrm{g}}\right)\end{array}$} & \multicolumn{3}{|c|}{ Number of organisms observed in tissue } \\
\hline & & $\begin{array}{l}\text { Tissue at the site } \\
\text { of infection }\end{array}$ & Liver & Spleen \\
\hline 162 & \multirow{13}{*}{10} & - & - & - \\
\hline 163 & & - & - & - \\
\hline 164 & & - & - & - \\
\hline 165 & & - & - & - \\
\hline 166 & & - & - & - \\
\hline 167 & & - & - & - \\
\hline 168 & & - & - & - \\
\hline 169 & & _- & - & - \\
\hline 170 & & - & - & - \\
\hline 171 & & - & - & - \\
\hline 172 & & - & - & - \\
\hline 173 & & - & - & - \\
\hline 174 & & - & - & - \\
\hline 175 & \multirow{12}{*}{1} & few & - & - \\
\hline 176 & & few & - & - \\
\hline 177 & & \# & - & - \\
\hline 178 & & very few & - & - \\
\hline 179 & & very few & - & - \\
\hline 180 & & very few & - & - \\
\hline 181 & & - & - & - \\
\hline 182 & & very few & - & - \\
\hline 183 & & very few & - & - \\
\hline 184 & & - & - & - \\
\hline $18 \overline{5}$ & & very few & - & - \\
\hline 186 & & - & - & - \\
\hline 188 & \multirow{13}{*}{ Control } & $\mathrm{Ht}$ & + & - \\
\hline 189 & & int & it & + \\
\hline 190 & & m & + & - \\
\hline 191 & & Ht & + & - \\
\hline 192 & & HI & Ht & + \\
\hline 193 & & $\mathrm{H}$ & - & - \\
\hline 194 & & tit & + & - \\
\hline $19 \overline{5}$ & & Hit & + & + \\
\hline 196 & & H & - & - \\
\hline 197 & & \# & + & - \\
\hline 198 & & H & + & - \\
\hline 199 & & W & + & - \\
\hline 200 & & $\mathrm{HH}$ & - & - \\
\hline
\end{tabular}

この実験成績は表 2 に総括した。治療群には外観上全 然病変は認められなかつた。䚯検の結果も，10 $\mathrm{mg}$ 投与 のものに於ては全く病変を認めず，顕微鏡的にも接稹部 位, 肝臟及び脾臟に抗酸性菌は証明されたかつた。 $1 \mathrm{mg}$ 投与のものに於ては，結節らしいものを4匹（No.177， 186，182，183）のマゥスに認めたが，抗酸性菌が稍々 多数に検出されたのは，その中の1匹（No.177）だけ で崖つて，他の 3 区に於ては，僅に証明されたに過ざな かつた。残り 9 匹のマウスに於ては，抗酸性菌の証明は 
困難であつたか，或は僅に認められた。対照マウスに於 ては, 接種後 2 カ月頃から結節が発生し, 剖検当日に於 ては，い声れも著明に結節もしくは潰瘍が認められ，そ の部に抗酸性菌が無数に証明され, また大多数に於て肝 臓及び脾臟にも多数の菌が検出された。

\section{考按}

ズルフォソ戍が人の瀨仙効果の专るととは, よく知ら れている。最近 INAH b鼠瀨の発症を阻止するととが 明かとなり, Hale, Molesworth, Russell and Lee ${ }^{7}$ 等は これを人癩に応用して，効果の台るととを認めた。しか し, Hobby and Donikian²によると, INAH はストレ プトマイシン及びプロミンのように, 治療を開始する時 に既に多数の鼠霣菌の存在する場合儿は, 抗菌作用を示 さないという。われわれも大体とれと同じよらな成績を 得大。

われわれが今回実験に用いた Isonicotinoyl-3-methoxy -4-hydroxybenzal hydrazone (No. 254) は, 著明な潰 瘍の存在する鼠賴心対しても効果があり, 完全にこれを 治瘾せしめる。潰㾨の治癔後, 治療を中止すると再発す る。との再発マウスに, No. 254 を再び与えても, 効果 は著明でない。抢そらく鼠籟菌か耐性を隻得したためと 思われるけれども，これに就ては目下研究中でもる。

治療期間が 3 力月以上に及ぶときは，抗酸性菌を接種 局所にすら証明するととは, 㕍々困難となる。との場合 組織に於ける菌の生死を試験するために，乙の組織をと つて健庹マウスに接種した結果によると, 接種後 6 カ月 までは発症を認めなかつたが，7 カ月目に1例発症し た。徉つて現在のとてろ, 組織内に於ける抗酸性菌が, 全部死んでいるとは考えられないが，更に治療を続ける ならば，死滅するかもしれない。

病理組織学的検査によると, 充分治療を行つたマウス に於ては，全然源性変化が認められない。

マウスに鼠瀨菌を接種し， 1 週を経てから No. 254 を 投与すると，発症は阻止される。充分な量が与えられた 場合には, 瀨性変化は全然現れないばかりでなく, 抗酸 性菌は接種部にすら認められない。

以上の成績から，われわれは No. 254 は鼠瀬菌に対 し, bacteriocidal に作用するで岕ろらと思ら。

\section{結論}

われわれは Isonicotinoyl-3-methoxy-4-hydroxybenzal hydrazone (No. 254) を鼠瀨の治療 及び発症阻止試験に 用いて，次のような成績を得た。
1. 鼠癩による潰癔もしくは結節の著明なマウスの皮 下に No. 254 を注射するか，或は経口的に与えると， 約 $2 \sim 3$ カ月後に局所の病変は完全に治瘾し, その後な 打治療を続けると, 内臓伦於ける抗酸性菌は消失し, 接 種局所に於ける抗酸性菌も榆出極めて困難となるか，1 視野心数コを算するのみとなる。

2. 㣴瘍の治癋後, 間もなく治療を中止すると, 往々 再発し, 再び治療を行つても治瘾困難のよらである。怙 そらく不完全な沿療のために，抗酸性菌が耐性を得たも のと考えられるけれども，この点については目下な打研 究中である。

3. 接稞局所の病変の治瘾後, な扣数週間治療を行つ てから，接種部の筋肉をとつて健唐マウスに接種したと ころ, 接種後 6 カ月までは発应を認めなかつたが, 7 カ 月目に 1 例だ计登症した。その他の 4 例に於ては，未代 晎常を認めない。それ故に治療を長期仁亘つて行つたな らば，鼠霣菌は死滅するかも知れない。

4. マウスに鼠瀨菌を接種後 1 週間経て, No. 254 を $10 \mathrm{mg}$ 毎日投与すると, 発庭は完全に阻止されるばかり でなく，接種部に抗酸性菌も証明されない。1 mg 投与 群に於ても発症は著しく阻止され，12匹中 3 匹に於ては 抗酸性菌は全く認められず，7 匹に於ては僅に証明さ れ，1 匹に於ての夕稍々多数に検出された。対照に於て は著明な発症と； その部に無数の抗酸性菌が認められ た。

6. 以上の実験成績か:ら，Isonicotinoyl-3-methoxy-4 -hydroxybenzal hydrazone は鼠瀨菌に対し, bacteriocidal に作用するもののよらに思われる。

本研究の一部は文部省科学研究費によつた。また本研 究に於ける病理組織学的検查は本学病理学教室今井教授 の援助によつた。ととに厚く樑謝する。

\section{文献}

1) Chang, Y. T.: Chemotherapy of murine leprosy, III, Intern. J. Leprosy. 21. 57 (1953)

2) Hobby, G. L. and Donikian, M. A.: An evaluation of chmotherapeutic agents in the control of experimental infections due to M. leprae murium, Am. Rev. Tuberc., 72, 846, (1955)

3 ）西村真二, 河野通之：ヒドラジットによる鼠瀨の治 療実験 最新医学 7, 1202 (昭和27)

4）川口陽一郎, 野田隆雄: 鼠瀨に対するイソニコチン 酸ヒドラジットの影響 (学会抄録) レプラ 22,212 (昭和28) 
5 ) 高山保郎：INAH 投与の 鼠瀨の 発育阻止 並び汇治 療効果に就て レプラ 23,71（昭和29）

6）市原鶴雄, 藤田幸雄, 市原強, 野中実穗: 鼠瀨の治 療に関する研究（第 2 報）レプラ $\mathbf{2 4}, 33$ (昭和 30$)$
7) Hale, J. H. Molesworth, B. D., Russell, D. A. an Lee, L. H.: Isonicotinic hydrazide in the treatment of leprosy, Intern. J. Leprosy. 22. 297 (1954) 
平野・須子田論文附図
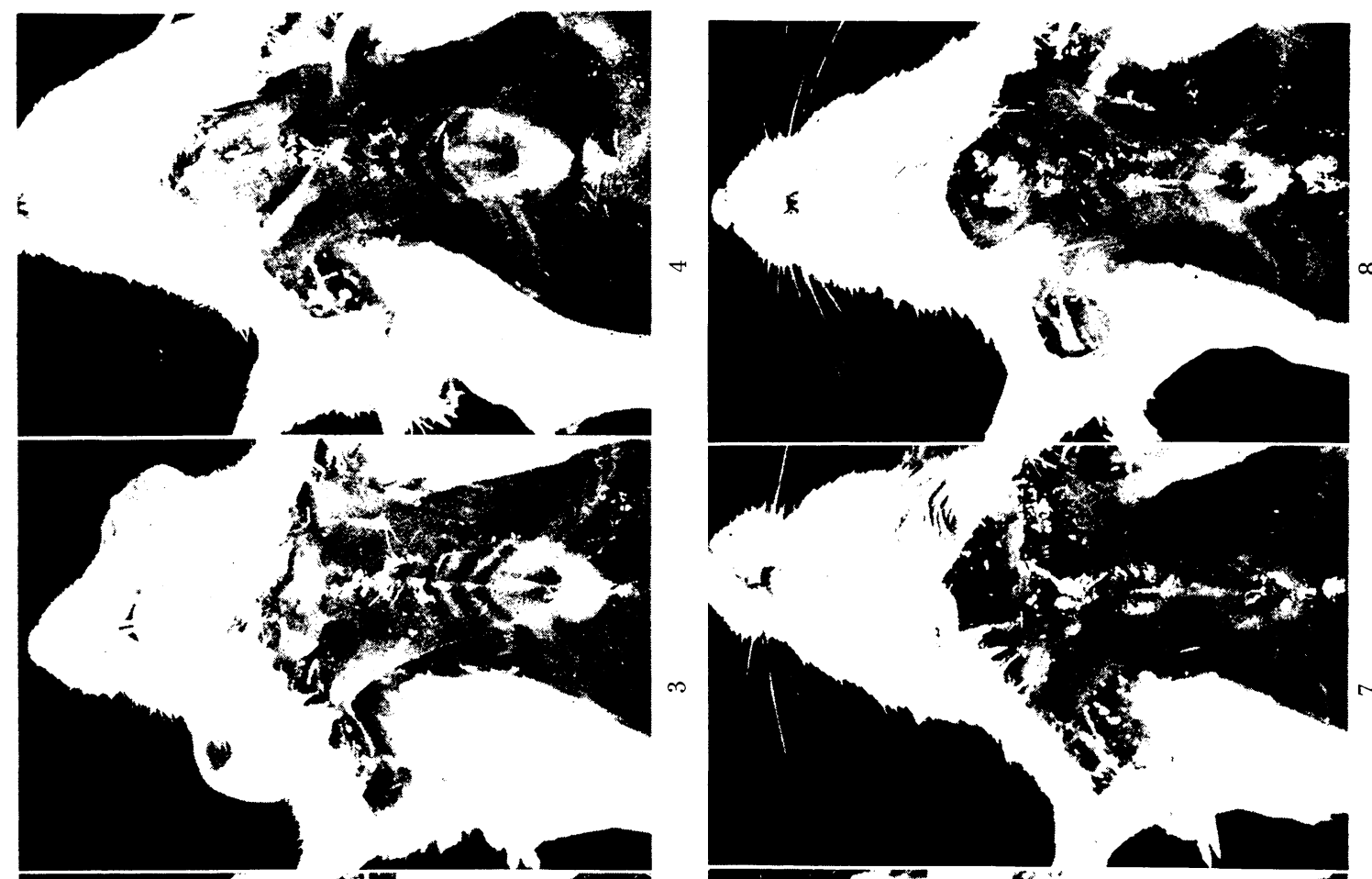

s.
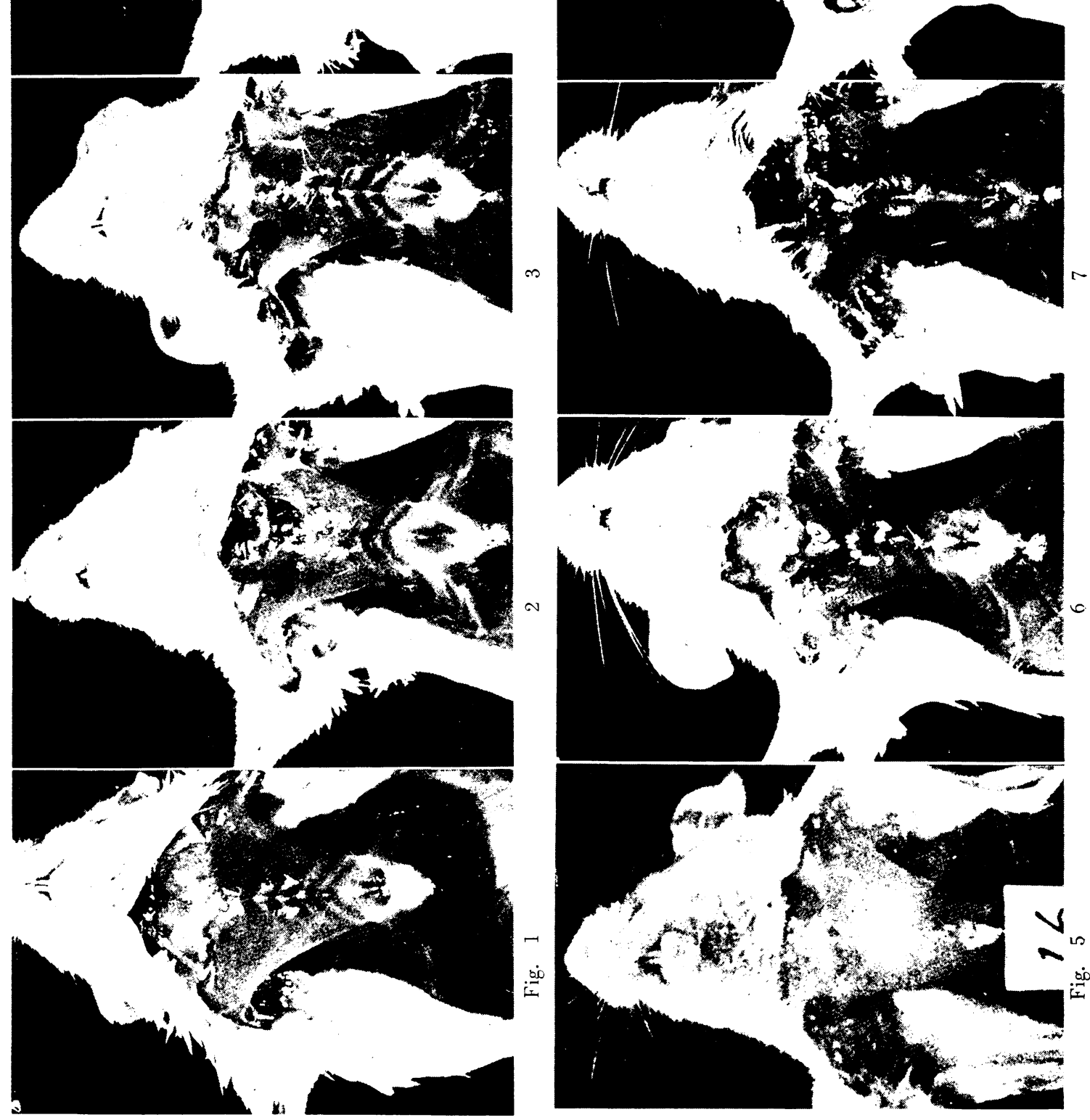
平影・須子田諭交附図

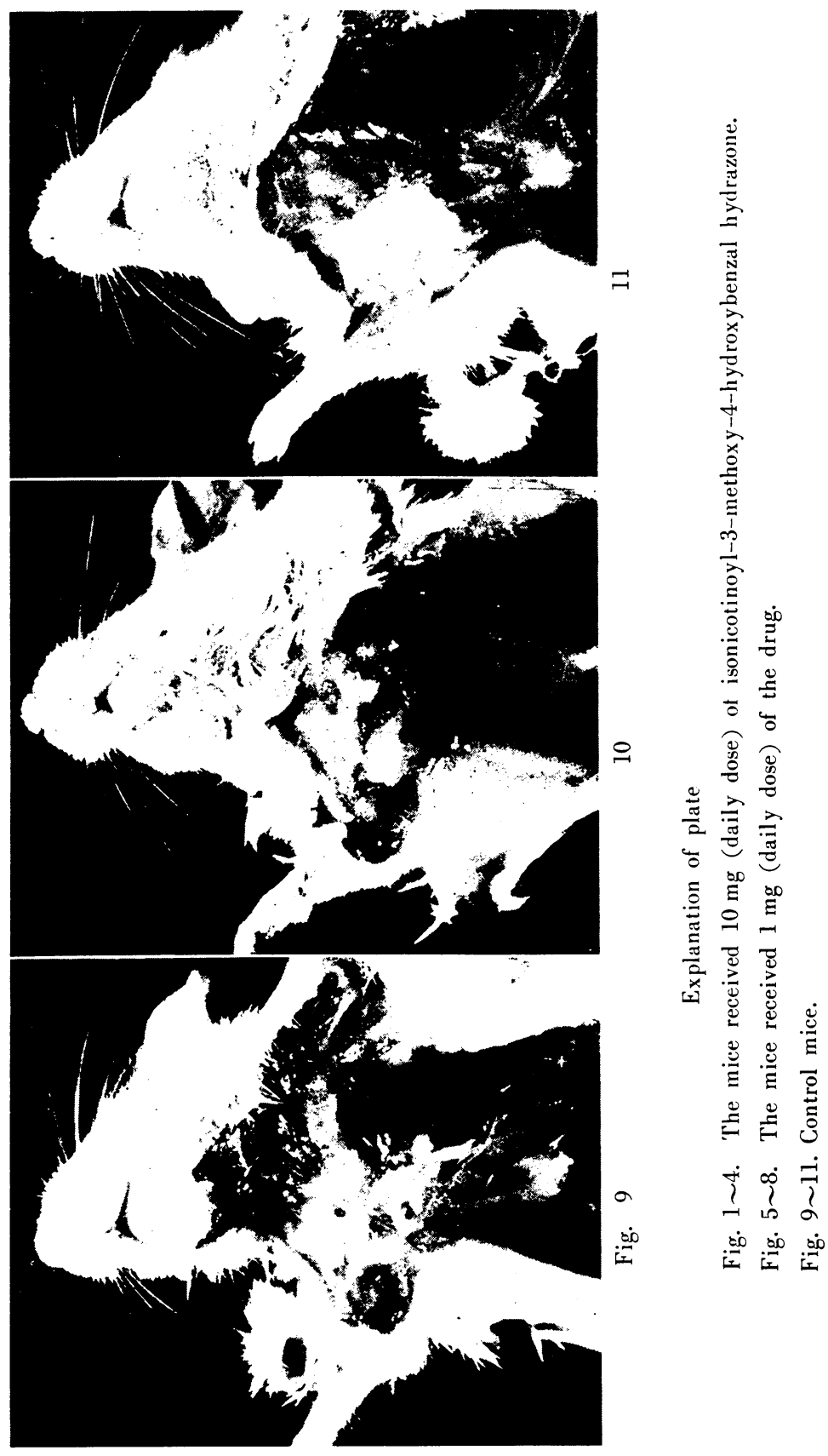

